이유자돈의 사료 첨가제로서 Copper Chelates(메치오닌, 키토산, 효모)의 효과

김병한·임희석·남궁환·백인기

중앙대학교 산업과학대학 동물자원과학과

\title{
Effect of Copper Chelates(Methionine-Cu, Chitosan-Cu and Yeast-Cu) as the Supplements to Weaning Pig Diet
}

B. H. Kim, H. S. Lim, H. Namkung and I. K. Paik

Department of Animal Science and Technology, College of Industrial Science, Chung-Ang University

\begin{abstract}
An experiment was conducted to study the effects of the dietary $\mathrm{Cu}$ sources on the performance of the weanling pigs. Forty-eight, 24 in each sex, 4 weeks old pigs were assigned to four treatments; control, methionine- $\mathrm{Cu}$ chelate, chitosan- $\mathrm{Cu}$ chelate or yeast-Cu chelate. Control diet contained 136ppm $\mathrm{Cu}$ to which additional 100ppm $\mathrm{Cu}$ in different chelated form was added to the respective treatment. Individual pig weight and feed intake of each pen were recorded weekly for 5 weeks. Average daily feed intakes(ADFI), average daily gains(ADG) and ADFI/ADG were not significantly different among treatments. Nutrient availability was not also significantly affected by treatments. Serum triglyceride concentration of chitosan- $\mathrm{Cu}$ treatment was significantly lower than those of methionine- $\mathrm{Cu}$ and yeast- $\mathrm{Cu}$ treatments but was not significantly different from that of the control. Serum cholesterol concentration of yeast- $\mathrm{Cu}$ was significantly lower than those of the control and methionine- $\mathrm{Cu}$ but was not significantly different from that of chitosan-Cu treatment. Serum HDL-cholesterol concentration was not significantly affected by treatments. Serum $\operatorname{IgG}$ concentrations of all copper treatments were significantly lower than that of the control. It was concluded that $\mathrm{Cu}$-chelates supplemented to the basal diet $(136 \mathrm{ppm} \mathrm{Cu})$ by the level of $100 \mathrm{ppm} \mathrm{Cu}$ did not significantly affect growth performance of weaning pigs. However, serum parameters of cholesterol, cholesterol and IgG were significantly affected by the treatments.
\end{abstract}

(Key words : Chelates, Copper, Methionine-Cu, Chitosan- $\mathrm{Cu}$, Yeast-Cu)

\section{I. 서 론}

돼지에서 높은 수준의 구리 공급은 성장률과 사료 섭취량, 사료효율에 개선을 가져왔다 (Braude, 1967; Edmonds 등, 1985). 특히 $\mathrm{CuSO}_{4}$. $5 \mathrm{H}_{2} \mathrm{O}$ 형태로 구리를 $125 \sim 250 \mathrm{ppm}$ 의 공급 시 성장율을 개선하는 것으로 알려져 널리 사용되
어 왔다. $\mathrm{Cu} \quad 125 \sim 250 \mathrm{ppm}$ 의 공급은 육계에서 혈액과 가슴근육 콜레스테롤의 함량을 감소시 킨다(Pesti와 Bakalli, 1996). 그리고, 구리 250 $\mathrm{ppm}$ 의 공급은 비육돈의 등지방내 포화지방산 을 감소시키고, 불포화지방산을 증가시켰다 (Amer와 Ellot, 1973). Hawbaker 등(1961)과 Stahly 등(1980)에 의하면 구리는 세균발육저지

본 연구는 농림부 농림기술센터의 첨단과제 연구비로 수행되었음.

Corresponding author: I. K. Paik, Dept. of Animal Science, Chung-Ang University, Ansung-Si, Kyonggi-Do, Korea 456-756 ikpaik@cau.ac.kr 
능력과 살균능력을 가지고 있는데 Stahly 등 (1980)이 어린 돼지(3 5주령) 사료에 구리 250 $\mathrm{ppm}$ 을 첨가 했을 때 항생제가 첨가된 사료와 성장효율을 비견할 수 있다고 하였다. 그러나 필수요구량 이상의 구리 사용은 구리의 배설량 증가로 인한 환경문제를 초래하므로 국내외적 으로 적정사용수준 $250 \mathrm{ppm}$ 의 절반수준인 100 $125 \mathrm{ppm}$ 으로 상한선을 제한하고 있다. 따라서 낮은 수준의 구리 사용량으로도 생산성 개선효 과를 얻기 위해서는 구리를 chelated form(Paik, 2001)으로 공급할 필요가 있다.

Chitosan은 항종양, 항균 및 항곰팡이 활성, 콜레스테롤 감퇴 및 고혈압 억제 작용 등 여러 가지 생리적 특성을 가지고 있음이 밝혀짐으로 써 현재 생리기능성 신소재로서 연구개발이 활 발히 진행되고 있는 물질이다(Muzzarelli 등, 1990; Kim 등, 1997; Kochkina 등, 2000). Chitosan은 Chtin의 acetyl기가 제거된 구조식을 갖고 있는데 chitin은 $\mathrm{pH}$ 6이상에서 $\mathrm{Cu}^{+2}$ 이온 과 거의 $80 \%$ 이상의 흡착능을 보였다(최, 1988).

Yeast는 사료 첨가제로써 여러가지 기능성을 가지고 있는데 특히 광물질을 흡수하여 유기태 로 전환시키는 능력이 뛰어나며 에너지를 이용 하여 다른 미네랄에 비해 특이하게 $\mathrm{Cu}^{+2}$ 를 받 아들이는 효모의 구리 흡수에 대한 높은 친화 도 시스템이 밝혀졌다(De Rome과 Gadd, 1987; Lin과 Kosman, 1990).

본 실험은 유기태 $\mathrm{Cu}$-chelates로 개발한 methionine- $\mathrm{Cu}$, chitosan- $\mathrm{Cu}$ 그리고 yeast- $\mathrm{Cu}$ 제품을 자돈에게 급여 했을 때 생산성과 혈액 내 지질 및 $\mathrm{IgG}$ 의 함량에 미치는 영향을 검토하기 위하 여 실시하였다.

\section{П. 재료 및 방법}

\section{1. 시험동물 및 시험설계}

약 4주령(28일령)의 3원 교잡종(Duroc $\times$ Yorkshire $\times$ Landrace) 이유자돈 48 두(송 24, 우 24) 를 공시하였으며, 시험 개시 평균체중은 $7.37 \pm$ $0.1 \mathrm{~kg}$ 이었고, 처리당 12 두를 암수 각 2 cage씩, cage당 3 두씩 임의로 배치하여 개체를 반복단
위로 하였으며 사료섭취량, 사료 요구율 및 영 양소 이용률의 경우는 반복단위를 cage로 하였 다.

\section{2. 시험사료}

옥수수-대두박 위주의 사료로써 NRC(1998) 사양표준을 기초로 하였다. 본 시험에 사용된 기본 배합표는 Table 1에서와 같고, 처리에 따

Table 1. Formula and composition of pigs basal diets

\begin{tabular}{lr}
\hline & Control \\
\hline \hline Corn & 64.35 \\
SBM & 23.57 \\
Corn gluten & 6.00 \\
Animal fat & 2.81 \\
Tricalcium phosphate & 1.55 \\
Limestone & 0.53 \\
Lysine-HCl(99\%) & 0.63 \\
Hog primix ${ }^{1)}$ & 0.30 \\
Salt & 0.27 \\
Methionine (99\%) & 0.01 \\
Total & 100.00 \\
\hline
\end{tabular}

Calculated composition;

ME (kcal/kg)

Crude protein $(\%)$

3250

Lysine (\%) 1.25

Methionine (\%) 0.35

Tryptophan (\%) $\quad 0.22$

Threonine (\%) $\quad 0.76$

Calcium (\%) $\quad 0.80$

Phosphorus-avail (\%) $\quad 0.40$

Phosphorus-total (\%) 0.65

Sodium (\%) 0.15

Copper $(\mathrm{ppm})^{2)} \quad 136$

1) Hog premix contains the followings per kilogram : Vitamin A, 12,000,000IU; vitamin $\mathrm{D}_{3}, 2,000,000 \mathrm{IU}$; vitamin E, 35,000mg; vitamin $\mathrm{K}_{3}, 3,300 \mathrm{mg}$; Pantothenic acid, 20,000mg; vitamin $\mathrm{B}_{2}$, 3,000mg; vitamin $\mathrm{B}_{12}$, 33,000/g; Niacin, 30,000mg; Biotin, $100,000 \mathrm{gg}$; vitamin C, 40,000mg; $\mathrm{FeSO}_{4}, 73,500$ $\mathrm{mg} ; \mathrm{ZnSO}_{4}, 56,000 \mathrm{mg} ; \mathrm{MnSo}_{4}, 15,750 \mathrm{mg} ; \mathrm{CuS0}_{4}$, $86,100 \mathrm{mg} ; \quad \mathrm{Ca}\left(\mathrm{IO}_{3}\right)_{2}, \quad 175 \mathrm{mg} ; \quad \mathrm{Na}_{2} \mathrm{SO}_{3}, \quad 105 \mathrm{mg}$; $\mathrm{CoSO}_{4}, 157 \mathrm{mg} ; \mathrm{S}, 17,500 \mathrm{mg}$.

2) Assayed value. 
라 기초 대조구 사료에 Paik 등(1999)의 방법으 로 제조한 methionine-Cu와 이 등(2001)의 방법 으로 제조한 chitosan-Cu 및 김 등(2001)의 방 법으로 제조한 yeast-Cu를 각각 $\mathrm{Cu} 100 \mathrm{ppm}$ 수 준에서 첨가하였다.

Methionine- $\mathrm{Cu}$ 구 : methionine- $\mathrm{Cu}(\mathrm{Cu}$ 함량 16.5

\%) $61 \mathrm{~g} / 100 \mathrm{~kg}$

Chitosan- $\mathrm{Cu}$ 구 : chitosan- $\mathrm{Cu}(\mathrm{Cu}$ 함량 $7.18 \%)$ $140 \mathrm{~g} / 100 \mathrm{~kg}$

Yeast-Cu구 : yeast- $\mathrm{Cu}(\mathrm{Cu}$ 함량 $2.2 \%) \quad 500 \mathrm{~g} /$ $100 \mathrm{~kg}$

\section{3. 사양관리 및 대사시험}

공시 자돈들을 cage에 배치한 후 시험 시작 하기 전 4 일간의 적응기간을 가진 후 5 주간의 사양시험을 실시하였다. 시험 기간동안 사료와 물은 자유 급식케 하였다.

증체량과 사료 섭취량은 매주 측정하였다. 대사 시험은 사양시험 4 주째에 $\mathrm{Cr}_{2} \mathrm{O}_{3}$ 를 사료내 $0.4 \%$ 첨가하여 3 일간 하루에 2회씩 채취하여 $60{ }^{\circ} \mathrm{C}$ 의 건조기에서 72 시간 건조 후 분쇄하여 공시하였다.

\section{4. 채 혈}

5 주간의 사양시험을 종료 후 모든 자돈의 경 정맥에서 채혈하여 상온에서 약 2시간 방치하 여 혈액을 응고시킨 후 $4{ }^{\circ} \mathrm{C} 3,000 \mathrm{rpm}$ 에서 15 분간 원심 분리하여 혈청을 채취 $-20^{\circ} \mathrm{C}$ 에서 보관하였다.

\section{5. 일반 조성분 분석 및 광물질 함량 측정}

시료의 조성분은 $\mathrm{AOAC}(1990)$ 방법에 준하여 실시하고, 사료와 분내 $\mathrm{Cr}$ 와 $\mathrm{Cu}$ 의 농도는 시료 를 $\mathrm{HNO}_{3}$ 와 $\mathrm{HCl}$ 로 전처리 한 다음 $\mathrm{ICP}$ (Inductively Coupled Plasma) 분광기를 이용하여 측정 한다.

6. 소화율 측정
일반성분의 소화율은 간접방법으로 다음의 계산식에 의하여 구하였다.

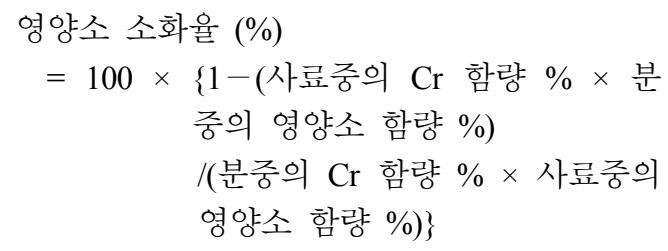

\section{7. 혈청내 IgG 농도 및 Triglyceride, Total Cholesterol and HDL-cholesterol 함량 측정}

혈청 내 $\mathrm{IgG}$ 농도는 Mancini (1965)에 의해 개발된 single radial immuno-diffusion test (RID test)법에 준하여 측정한다. 혈청내 triglyceride, total cholesterol and HDL-cholesterol 함량측정 은 Sigma Diagnostic Kits (No. 352, Total Cholesterol; No. 352-3, HDL; No. 336, Triglyceride) 를 이용하여 분석하였다.

8. 통계처리

실험 결과들은 $\mathrm{SAS}^{\circledR}(1990)$ 의 $\mathrm{GLM}$ (general Linear Model) Procedure를 통해 분석하였으며, 처리 평균치간 차이의 검정은 Duncan's new multiple range test로 $\mathrm{p}<0.05$ 수준에서 실시하였 다.

\section{III. 결과 및 고찰}

5주간 사양실험의 성적(Table 2)을 보면 처음 3(1 21d)주간은 증체량에서 chitosan- $\mathrm{Cu}$ 처리가 조금 낮았지만 유의차는 없다. 사료섭취량은 chitosan- $\mathrm{Cu}$ 처리구가 적었지만 역시 유의차는 없었다. 사료전환율에서 chitosan- $\mathrm{Cu}$ 처리구가 낮지만 유의차는 없었다. 후반 2주(22 35d)동안 증체량을 보면 chitosan- $\mathrm{Cu}$ 처리구가 증체량이 비교적 높고 yeast- $\mathrm{Cu}$ 처리가 낮으나 유의차는 없었다. 사료 섭취량에서는 methionine- $\mathrm{Cu}$ 구가 낮고 chitosan- $\mathrm{Cu}$ 구가 높으나 유의차는 없었다. 사료 전환율은 methionine- $\mathrm{Cu}$ 구가 낮으나 역시 
Table 2. Effect of Cu-chelate on the performance of weanling pigs fed 35 days

\begin{tabular}{|c|c|c|c|c|c|c|}
\hline & & \multicolumn{4}{|c|}{ Treatments } & \multirow{2}{*}{ SEM } \\
\hline & & Control & Methionine-Cu & Chitosan-Cu & Yeast-Cu & \\
\hline & Initial wt $(\mathrm{kg})$ & 7.37 & 7.36 & 7.36 & 7.42 & 0.10 \\
\hline & Final wt (kg) & 21.66 & 21.69 & 21.78 & 21.39 & 0.41 \\
\hline \multirow{3}{*}{$\begin{array}{l}0 \sim 21 \\
\text { days }\end{array}$} & ADG (g) & 348.02 & 346.89 & 340.11 & 341.61 & 13.28 \\
\hline & ADFI (g) & 574.47 & 573.83 & 553.06 & 566.98 & 32.42 \\
\hline & $\mathrm{ADFI} / \mathrm{ADG}$ & 1.65 & 1.65 & 1.63 & 1.66 & 0.09 \\
\hline \multirow{3}{*}{$\begin{array}{c}22 \sim 35 \\
\text { days }\end{array}$} & ADG (g) & 498.75 & 502.83 & 517.92 & 485.47 & 13.14 \\
\hline & ADFI (g) & 1003.00 & 965.75 & 1008.75 & 980.00 & 49.74 \\
\hline & ADFI/ADG & 2.01 & 1.92 & 1.98 & 2.02 & 0.09 \\
\hline \multirow{3}{*}{$\begin{array}{l}0 \sim 35 \\
\text { days }\end{array}$} & ADG (g) & 408.31 & 409.26 & 411.23 & 399.14 & 10.91 \\
\hline & ADFI (g) & 745.94 & 730.63 & 738.85 & 732.24 & 37.29 \\
\hline & ADFI/ADG & 1.83 & 1.79 & 1.81 & 1.83 & 0.07 \\
\hline
\end{tabular}

유의차는 없었다. 전 기간을 보면 일당 증체량 은 chitosan- $\mathrm{Cu}$ 처리구가 높았고, yeast-Cu 처리 가 낮았지만 유의차는 없다. 마찬가지로 사료 섭취량과 사료 전환율도 처리간에 유의한 차이 가 없었다.

Stahly 등 $(1980)$ 이 실험한 $28 \pm 2$ 일령의 $6.75 \mathrm{~kg}$ 돼지에서 14 일간 실험한 결과 $\mathrm{Cu} 125 \mathrm{ppm}$ 첨가 구가 대조구보다 높은 증체량과 사료섭취량을 보였다. 일당 증체량이 $226 \mathrm{~g}$ 에서 $260 \mathrm{~g}$ 으로 증 가하였고, 섭취량은 $430 \mathrm{~g}$ 에서 $497 \mathrm{~g}$ 로 증가하였 다. 그리고, Cromwell 등(1998)이 27일령의 이 유자돈을 31 일동안 실험한 결과 증체량에서 구 리 $200 \mathrm{ppm}\left(\mathrm{CuSO}_{4}\right)$ 첨가구가 대조구보다 높았 고 $(\mathrm{p}<0.08)$ 사료 섭취량도 마찬가지로 구리 첨 가구가 대조구보다 높았다 $(\mathrm{p}<0.01)$. 하지만 Stansbury 등(1990)은 $\mathrm{CuSO}_{4}$, inorganic(EDTA) chelated $\mathrm{Cu}$ 와 organic (amino acids or polysaccharides) chelated $\mathrm{Cu}$ 로 $28 \pm 2$ 일령 돼지에서 단계별로 실험을 하였다. 여기서 $6.4 \sim 18 \mathrm{~kg}$ 단계 에서 증체량, 사료 섭취량과 사료효율을 보면
본 실험과 마찬가지로 유의차가 없었다. 그런 데 $18 \sim 64 \mathrm{~kg}$ 단계에서 보면 $\mathrm{Cu} 125 \mathrm{ppm}$ 처리구 들에서 유의하게 생산성을 개선시켰다. $\mathrm{Cu}$ (copper sulfate)를 100 250ppm 급여 할 때 돼지 의 성장을 자극한다(Braude 등, 1967; Cromwell 등, 1997). Cromwell 등(1998)이 대조구와 구리 $\left(\mathrm{Cu}[\mathrm{OH}]_{3} \mathrm{Cl}\right)$ 를 100,150 과 $200 \mathrm{ppm}$ 씩 첨가가하 여 실험한 결과 증체량에서 $150 \mathrm{ppm}$ 첨가구 $(599 \mathrm{~g})$ 와 $200 \mathrm{ppm}$ 첨가구 $(589 \mathrm{~g})$ 간에 차이를 보 이지 않았다. 본 실험에서 대조구의 $\mathrm{Cu}$ 함량이 $136 \mathrm{ppm}$ 으로 이미 요구량보다 훨씬 높아 $\mathrm{Cu}$ $100 \mathrm{ppm}$ 을 추가로 첨가한 처리구들과 유의적 차이를 보이지 않았으며 chelate 형태도 영향이 없었던 것으로 사료된다.

Table 3은 시험사료의 영양소 이용률 실험의 결과이다. 고형물, 조단백, 조지방, 조회분과 $\mathrm{NFE}$ 에서 처리간에 유의차를 보이지 않았다. 조회분의 이용률을 보면 methionine- $\mathrm{Cu}$ 구가 chitosan- $\mathrm{Cu}$ 와 yeast- $\mathrm{Cu}$ 구보다 낮았으나 유의차 는 없었다. 
Table 3. Nutrient digestibility of experimental diets

\begin{tabular}{lccccc}
\hline \multirow{2}{*}{ Item(\%) } & \multicolumn{4}{c}{ Treatments } & \multirow{2}{*}{ SEM } \\
\cline { 2 - 5 } & Control & Methionine-Cu & Chitosan-Cu & Yeast-Cu & \\
\hline \hline DM & 82.55 & 82.87 & 83.26 & 83.96 & 0.65 \\
Crude protein & 78.48 & 78.31 & 79.32 & 80.38 & 0.73 \\
Ether extract & 61.31 & 60.30 & 60.65 & 59.07 & 2.77 \\
Crude ash & 52.64 & 50.80 & 58.86 & 59.79 & 4.63 \\
NFE & 89.59 & 90.51 & 89.59 & 90.33 & 0.76 \\
\hline
\end{tabular}

Table 4. Serum Triglyceride, total cholesterol and HDL-cholesterol of pigs fed experimental diets

\begin{tabular}{lccccc}
\hline & \multicolumn{4}{c}{ Treatments } & \multirow{2}{*}{ SEM } \\
\cline { 2 - 5 } & Control & Methionine-Cu & Chitosan-Cu & Yeast-Cu & \\
\hline \hline Triglyceride $(\mathrm{mg} / \mathrm{dL})$ & $40.43^{\mathrm{ab}}$ & $52.67^{\mathrm{a}}$ & $34.99^{\mathrm{b}}$ & $49.91^{\mathrm{a}}$ & 4.73 \\
Total cholesterol $(\mathrm{mg} / \mathrm{dL})$ & $99.43^{\mathrm{a}}$ & $95.55^{\mathrm{a}}$ & $90.63^{\mathrm{ab}}$ & $81.49^{\mathrm{b}}$ & 3.33 \\
HDL-cholesterol $(\mathrm{mg} / \mathrm{dL})$ & 28.44 & 28.87 & 22.27 & 24.39 & 2.68 \\
\hline
\end{tabular}

a-b Values with different superscripts in the same row are significantly different $(p<0.05)$.

Triglyceride, total cholesterol과 HDL-cholesterol의 혈청 내 함량(Table 4)을 보면 triglyceride에서 chitosan- $\mathrm{Cu}$ 처리구가 methionine- $\mathrm{Cu}$ 와 yeast- $\mathrm{Cu}$ 처리보다 유의하게 낮았으나 대조 구와는 유의한 차이가 없었다. Total cholesterol 은 yeast-Cu 처리가 대조구나 methionine-Cu보 다 유의하게 낮았으며 chitosan- $\mathrm{Cu}$ 와는 유의차 가 없었다. HDL-cholesterol은 methionine- $\mathrm{Cu}$ 처 리와 대조구가 타 처리구들 보다 높았으나 유 의차는 없었다.

Paik 등(1999)이 육계에서 실험한 결과에서 cholesterol 함량을 보면 대조구가 $151.5 \mathrm{mg} / \mathrm{dL}$ 로 높고 $\mathrm{CuSO}_{4}-250$ 처리가 $126.8 \mathrm{mg} / \mathrm{dL}$ 로 낮게 나 왔고 methionine-Cu-125 처리는 $138.7 \mathrm{mg} / \mathrm{dL}$ 로 낮으나 유의차는 없었다. $\mathrm{HDL}$ 은 대조구보다 모든 처리구에서 높았으나 유의차는 없었다. 한편, Engle 등(2000)의 실험에서 숫송아지의 triglyceride 함량은 대조구, Cu-citrate와 Cu-proteinate 처리구에서 처리간에 비슷한 결과를 보 였고 $\mathrm{HDL}$ 함량은 대조구보다 Cu-chelate 첨가 구에서 낮은 함량을 보였으나 유의차는 없었 다.

혈청내 $\mathrm{IgG}$ 농도 (Fig. 1)는 $\mathrm{Cu}$ 처리구들(methionine- $\mathrm{Cu} ; 23.06 \mathrm{mg} / \mathrm{mL}$, chitosan- $\mathrm{Cu} ; 19.46 \mathrm{mg}$, yeast-Cu; $21.73 \mathrm{mg})$ 이 대조구 $(30.00 \mathrm{mg})$ 보다 낮 았다.

Yeast-chelate에서 효모는 맥주효모를 이용하 였고 이 효모는 전축종에 단백질 공급원으로 이용되고 있다. 효모의 세포벽은 전체 무게의 약 $30 \%$ 를 차지하고 있는 올리고당으로 되어 있다(Lyons 등, 1986). Spring과 Privulescu(1998) 는 올리고당이 자돈의 면역체계에 미치는 영향 을 구명하고자 무균돈구와 일반돈구에 올리고 당을 급여하여 면역반응을 조사하고 다음과 같 


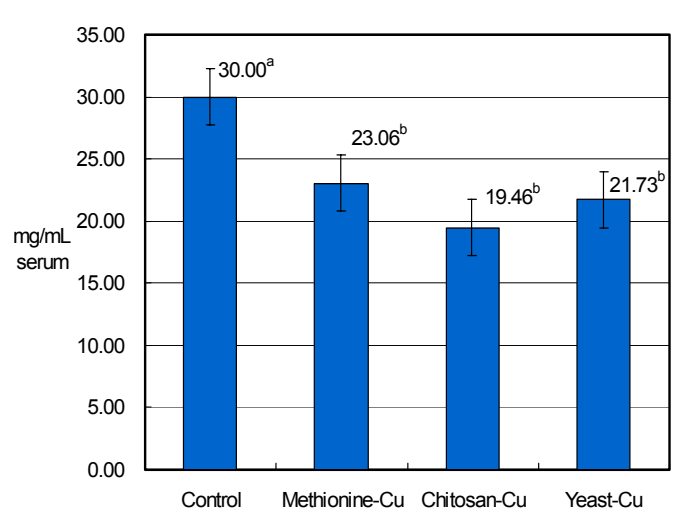

Fig. 1. Serum IgG of pigs fed experimental diets.

a-b Values with different superscripts in the same row are significantly different $(\mathrm{p}<0.05)$.

은 결과를 제시하였다. 올리고당의 첨가는 무 균돈구와 일반돈구 모두에서 immunoglobulin의 농도를 증가 시켰다. 하지만 일반돈구의 혈청 $\mathrm{IgG}$ 의 량은 차이를 보이지 않았다. 오히려 대 조구 $(1,638 \mathrm{mg} / 100 \mathrm{~mL})$ 가 첨가구 $(1,619 \mathrm{mg} / 100$ $\mathrm{mL}$ )보다 조금 높았다. Dréau와 Lallès(1999)가 자돈에게 낮은 항원성사료를 공급한 처리구가 대조구에 비하여 낮은 $\operatorname{IgG}$ 농도를 보였다. 그 리고, 이것은 항생제, 구리와 아연 등에도 낮은 항원사료라는 개념을 적용할 수 있다고 하였 다. 한편 김 등(1997)은 자돈 설사를 일으키는 대장균에 대해 키토산의 항균효과를 조사하였 는데 키토산 첨가구에서 대장균에 대한 항균작 용이 있다고 밝혔다. 본 실험에서도 다른 $\mathrm{Cu}$-chelate 첨가구 보다 chitosan- $\mathrm{Cu}$ 첨가구가 더 낮은 $\operatorname{IgG}$ 함량을 보였는데 유의성은 없었 다. 본 실험에서 $\mathrm{Cu}$-chelate 처리구가 대조구에 비해 혈청 $\mathrm{IgG}$ 수준이 낮은 것은 소화기에서 항생제와 같은 살균작용을 통하여 항원성 인자 를 감소 시킴으로서 면역계에 적은 자극을 준 결과라고 추정할 수 있다. 또 $\mathrm{Cu}$ 나 항생제의 효과는 새로운 또는 청결한 시설에서 실험하거 나 건강한 동물에서는 효과를 거의 보이지 않 는다(Kornegay 등, 1975). 본 실험은 실험돈사 에서 청결한 cage 사육으로 이루어졌고 대조구 사료에 이미 약리적사용 수준에 가까운 136 $\mathrm{ppm}$ 의 구리가 함유되어 있어 $\mathrm{Cu}$-chelates에 의
한 $\mathrm{Cu}$ 의 추가적 공급이 생산성에 유의한 차이 를 나타내지 못한 것으로 사료된다. 그러나 혈 청의 지질과 $\mathrm{IgG}$ 수준에는 유의한 영향을 미쳤 는데 혈청 triglyceride는 chitosan- $\mathrm{Cu}$ 처리에서 감소되었으며, total cholesterol은 yeast-Cu 처리 에서 감소되었고, $\mathrm{Cu}$-chelate 첨가구들에서 $\mathrm{IgG}$ 가 감소되었다.

\section{IV. 요 약}

본 시험은 이유자돈사료에 Cu-chelates를 첨 사시 자돈의 생산성과 혈액지질 및 $\mathrm{IgG}$ 수준에 미치는 영향을 측정하기 위하여 실시하였다. 4 주령 된 이유자돈 48마리(암 - 수 각 24마리)를 4처리 4반복으로 반복 당 3 마리씩 암수 구별하 여 실시하였다. 본 시험에서 사용된 대조구 사 료에는 $137 \mathrm{ppm}$ 의 구리가 함유되어 있으며 각 처리구는 대조구사료에 methionine- $\mathrm{Cu}$ chelate, chitosan- $\mathrm{Cu}$ chelate와 yeast- $\mathrm{Cu}$ chelate를 $\mathrm{Cu}$ $100 \mathrm{ppm}$ 수준에서 각각 첨가하였다. 5 주간의 사 양기간 동안 증체량은 개체 단위로, 사료섭취 량은 pen 단위로 매주 측정을 하였다.

일당 증체량, 사료 섭취량, 사료효율 그리고, 영양소 이용률은 모두 처리간에 유의차를 보이 지 않았다. 혈청 내 triglyceride 함량은 chitosan- $\mathrm{Cu}$ 처리가 methionine- $\mathrm{Cu}$ 나 yeast- $\mathrm{Cu}$ 처리보 다 유의하게 낮았으나 대조구와는 유의한 차이 를 보이지 않았다. 혈청 내 cholesterol 함량은 yeast- $\mathrm{Cu}$ 처리가 대조구와 methionine- $\mathrm{Cu}$ 처리 보다 유의하게 낮았지만 chitosan- $\mathrm{Cu}$ 처리와는 유의한 차이가 없었다. 혈청 $\mathrm{IgG}$ 의 함량은 대 조구 보다 모든 $\mathrm{Cu}$-chelate 처리구에서 낮게 나 타났다.

결론적으로 $\mathrm{Cu} 137 \mathrm{ppm}$ 의 대조구 사료에 $\mathrm{Cu}$ $100 \mathrm{ppm}$ 수준에서 첨가한 $\mathrm{Cu}$-chelates는 이유자 돈의 증체량, 사료섭취량과 사료효율에 유의한 영향을 미치지 않았으나, 혈청 내 지질의 조성 과 $\mathrm{IgG}$ 함량에는 유의한 영향을 미쳤다.

(색인 : Chelate, 구리, 메치오닌-Cu, 키토산-Cu, 효모-Cu)

\section{$\mathrm{V}$. 인 용 문 헌}


1. Amer, A. M. and Elliot, J. I. 1973. Effects of level of copper supplement and removal of supplemental copper from the diet on the physical and chemical characteristics of porcine depot fat. Can. J. Anim. Sci. 53:139-145

2. Association of Offical Analytical Chemist, 1990. Official Methionineods of Analysis. 15thed. Association of Offical Analytical Chemists, Arlington, VA.

3. Braude, R. 1967. Copper as a stimulant in pig feeding(cuprum propecunia). World Rev. Anim. Prod. 3:69.

4. Cromwell, G. L. 1997. Copper as anutrient for animals. Pp. 177-202 in Handbook of copper compounds and applications, H. W. Richardson, Ed. New York: Marcel Dekker, Inc.

5. Cromwell, G. L. 1998. Tribasic copper chloride and copper sulfate as copper sources for weanling pigs. J. Anim. Sci. 76(1):118-123.

6. De Rome, L. and Gadd, G. M. 1987. Measurment of copper uptake in Saccharomyces cerevisiae using a $\mathrm{Cu} 2+$ selective electode. FEMS Microbiol. Lett. 43:283-287.

7. Dréau, D. and Lallès, J. P. 1999. Contribution to the study of gut hypersensitivity reactions to soybean proteins in preruminant calves and earlyweaned piglets. Livestock production science. 60: 209-218.

8. Edmonds, J. S., Izquiendo, O. A. and Baker, D. H. 1985. Feed additive studies with newly weaned pigs: Efficacy of supplemental copper, antibiotics and organic acids. J. Anim. Sci. 60:462-479.

9. Hawbaker, J. A., Speer, V. C., Hays, V. W., Hawbaker, J. H. and Catron, D. V. 1961. Effects of copper sulfate and other chemotherapeutics in growing swine rations. J. Anim. Sci. 20:163.

10. Kim, C. H., Choi, J. W., Chun, H. J. and Choi, S. K. 1997. Synthiesis of chitosan derivatives with quaternary ammonium salt and their antibacterial activity. Polymer Bulletin. 38(4):387393.

11. Kochkina, Z. M. and Chirkov, S. N. 2000. Influence of chitosan derivatives on the development of phage infection in the Bacillus thuringiensis culture. Microbiology. 69(2):217-219.

12. Kornegay, E. T., Thomas, H. R. and Kramer, C. Y. 1975. Effect on subsequnt feedlot performance of rotating or withdrawing dietary antibiotics from swine growing and finishing rations. J. Anim. Sci. 41:1555.

13. Lin, C. M. and Kosman, D. J. 1990. Copper uptake in wild type and copper metallothionein deficient Saccharomyces cerevisiae. J. Biol. Chem. 265:9194-9200.

14. Lyons, P. 1986. Yeast: out of the black box. Feed managemant. Vol. 37(10):8-14.

15. Mancini, G., Carbonara, A. O. and Heremans, J. F. 1965. Immunochemical quantitation of antigens by single radial immunodiffusion. Immunochemistry 2:235-254.

16. Muzzarelli, R., Tarsi, R., Filippini, O., Glovanetti, E., Graziella, B. and Varaldo, P. E, 1990. Antimicrobial properties of N-carboxybutyl chitosan. Antimicrobial Agents and Chemotherapy. 34(10): 2019-2023.

17. Paik, I. K. 2001. Management of excretion phosphorus, nitrogen and pharmacological level minerals to reduce environmental pollution from animal production. Asian-Aus. J. Anim. Sci. 14 (3):384-394.

18. Paik, I. K., Seo, S. H., Um, J. S., Chang, M. B. and Lee, B. H. 1999. Effects of Supplementary copper-chelate on the performance and cholesterol level in plasma and breast muscle of broiler chickens. Asian-Aus. J. Anim. Sci. 12(5):794-798.

19. Pesti, E. G. and Bakalli, R. I. 1996. Studies on the feeding of cupric sulfate penthahydrate and cupric citrate to broiler chickens. Poult. Sci. 75: 1086-1091.

20. Spring, P. and Privulescu, M. 1998. Mannanoloigosaccharide: Its logical role as a natural feed additive for piglets. Proceedigs of 8th WCAP, Pre-Conference Symposia. pp. 21-27.

21. Stahly, T. S., Cromwell, G. L. and Monegue, H. J. 1980. Effects of the dietary inclusion of copper and antibiotics on the performance of weaning pigs. J. Anim. Sci. 51:1347-1352. 
22. Stansbury, W. F., Tribble, L. F. and Orr, D. E. Jr. 1990. Effect of chelated copper sources on performance of nursery and growing pigs. J. Anim. Sci. 68:1318-1322.

23. 김형기, 문성현, 김우연. 2001. 황산동 첨가배지 에서 배양한 효모의 구리함량 조사. 유전공학연 구논집. 중앙대학교. 14(1):81-86.

24. 김희경, 김희선, 강문일, 고홍범, 김종염, 이응호. 1997. 자돈 설사 유발 대장균에 대한 Chitosan의 항균효과. 한수공보지. 21(2):97-105.
25. 이윤기, 백인기, 장문백, 손태일. 2001. 고분자량 chitosan mineral chelate의 제조와 사료첨가제로 서의 응용. 식량자원연구소 논문집. 중앙대학교. 13(1):61-68.

26. 최규석. 1988. 천연 chlate 고분자인 chitin의 화학 적 처리와 그 금속이온 흡착특성에 관한 연구. Bulletin of Environmental Science. 9:13-22.

(접수일자 : 2002. 11. 27 / 채택일자 : 2003. 1. 24) 